ance from one kind of bacterium to another has only since been recognized. Moreover, the emergence and prevalence of drug-resistant strains of bacteria in animal husbandry has only more recently become substantial. The most obvious danger is that the multiplication of resistant strains of pathogenic bacteria will take a serious toll of the animals now being kept in increasing numbers in conditions of intensive farming. More distantly, however, there is the grisly prospect that the prevalence of resistant bacteria among animals will throw up resistant human infections. In circumstances like these, it is more than a little fatuous for committees to say, as the Scientific Advisory Panel of the Ministry of Agriculture reported to its minister earlier this year (see Hansard, January 31, column 239), that "antibiotic resistance has always existed and this is one of the reasons why a wide range of antibiotics has been needed to control infections". The truth is that there is a real problem to be tackled even though it would be wrong at this stage to suggest that British veterinary practice has already passed the danger point. It will be a great surprise if Professor Swann's committee can answer all the questions that will be asked of it in the next few months.

What then is to be done? As things are, the use of three antibiotics as additions to pig and poultry food is permitted and the chances are that poultry farming has already become dependent on the use of these materials. But nobody has a very clear picture of the scale on which these materials are being used or of the economic benefit which they confer. Do farm animals grow fatter quicker if they are kept in dark houses and fed antibiotics than if they are allowed to roam more freely without medication? Quite apart from the risks to human health, these are difficult problems in animal husbandry which deserve the most careful attention. There are also important questions to be decided about the possibility of helping to keep the risk of accumulative resistance at bay by the careful management of livestock. The committee, under Professor Swann, seems to be anxious to take up all kinds of interesting problems like these as well as to give proper attention to the needs of human health and safety. The fear that the committee will turn out to be a lobby for the veterinarians, quite proper, seems to be unfounded. Whether the committee will fall a victim to that kind of conservatism the chief symptom of which is complacency remains to be determined.

Even at this stage, however, one general principle should be clear. Among the recommendations of the new committee there is certain to be an exhortation that "the situation should continue to be watched". The Swann committee may even go farther than its several predecessors in suggesting what kind of machinery there should be to carry out this task. It is anomalous that the British Government which, in fields like technology, is prone to shoulder more responsibility for research than it can comfortably manage, is in fields like this inclined to delegate responsibility to other organizations. In practice, for example, the chief agency for investigating experi- mentally the safety of food additives is the British Industrial Biological Research Association which is, in theory at least, a publicly supported consortium of industrial companies. In the same somewhat lackadaisical way, the Government tends to rely for advice on committees which are usually characterized by their combination of conflicting interests-a device which is as productive of compromise as of consensus. But in the long run it is hard to see how the British Government can avoid taking yet another leaf out of the American book and resolving to establish an autonomous agency, equivalent to the Food and Drug Administration, which would be free to make enemies if it pleases in a field in which some enemies are bound to be almost irreconcilable. This is the sense in which the working of the Swann committee will deserve, and will no doubt get, the closest attention.

\section{Minister in Trouble}

Mr EDward Short, the new Secretary of State for Education and Science, has been popular with teachers in his first few weeks of office but seems to be running into trouble with the universities and even with seientists. For one thing, the Council for Scientific Policy has written to $\mathrm{Mr}$ Short to complain that it was not kept properly informed about the decision not to participate in the $300 \mathrm{GeV}$ accelerator project at CERN. More openly, Professor Michael Swann, principal of the University of Edinburgh, has joined with the local head of the Association of University Teachers and the president of the Students' Council to protest at the things which $\mathrm{Mr}$ Short has been saying about the universities. What seems to have rattled the academics is $\mathrm{Mr}$ Short's request that "the authoritarian regimes which still persist in too many of our universities" should be liberalized. Professor Swann and his colleagues argue that this "sweeping condemnation ... can hardly fail to be used as an excuse by extremists for causing trouble" and, at the same time, strengthen "anti-student feeling" outside the universities. They go on to claim that British universities, and particularly Scottish universities, are as liberal as anybody could expect and they invite Mr Short to eat his words.

There is no doubt that this direct challenge to the minister by a distinguished academic breaks new ground in the relations between British universities and the government. If he is wise, Mr Short will read this as an ominous sign. Vice-chancellors at other universities will at the same time marvel at the cleverness with which Professor Swann has ensured that he will be supported by the representatives of his students and his staff if there is what people call trouble next academic year.

\section{Too Little, Too Thin}

Predictably the report of the Working Group on Molecular Biology (HMSO 2s. 6d.) of the Council for Scientific Policy makes gloomy reading. The working group, under the chairmanship of Dr J. C. Kendrew, says that there is too little research on molecular biology in Britain and that most of what there is tends to be so widely scattered that its value is dubious. According 
to the committee, British leadership in many areas of the field is steadily diminishing as workers in the United States and other countries take the initiative. The working group has reached the dismal conclusion that "we cannot sustain a desirable momentum in this country, or exploit the possibilities of advance which we clearly see ahead, unless we find ways of substantially increasing the numbers of first class biologists at the molecular level above the 50 to 100 we have today".

In an attempt to find out how many molecular biologists there are in Britain - and anyone with pretensions to being a biochemist, a cell biologist or molecular geneticist was included in that category-the working group surveyed the output of scientific papers in fifteen journals between. July 1964 and June 1966. The British output was about 500 papers and much of this work "is at best dull and at worst trivial" from 1,800 scientists. Altogether, this accounts for 12 per cent of the total population of biologists in Britain, and the working group considers this too small a proportion. Worse still, most of these are people working in virtual isolation or in groups which under existing conditions will never reach a critical mass.

The report criticizes the slowness with which undergraduate and post-graduate teaching programmes have been adapted to the new attitudes in biology which is, of course, a consequence of the small number of posts offering reasonable career prospects and research facilities for molecular biologists. There is no overall shortage of jobs for biologists but too many of the posts and too much of the available money support activities which "are by any reckoning quite out of date". "Inbreeding", the widespread tendency of universities to hang on to their best students and eventually recruit them as staff, and tenure obtained too early and too easily, contribute to this. And the failure to provide post-doctoral fellowships with decent salarics and research facilities encourages British postdoctoral fellows in the United States to remain. The

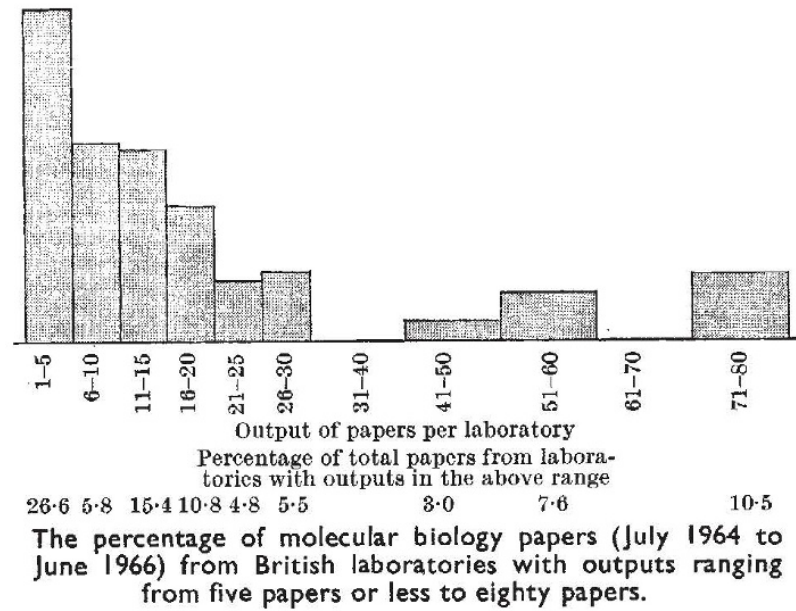

report sees no stopping the brain drain "unless conditions in Britain are greatly improved. One might seriously ask whether any other factor except sentiment prevents a wholesale emigration of the better workers". With the slim chance that the recommendations will be implemented in the near future, that is probably sound advice.

The working group also calls for a relaxation of the traditional departmental boundaries so that undergraduates receive a unified course in biology. At the post-graduate level, it advocates a preliminary year of course work on the American model before embarking on full time research. At the post-doctoral level, it asks for the provision of fellowships, again on the American model, to cover the years between the $\mathrm{PhD}$ degree and a university post. A prerequisite of further advance, however, is the establishment of what the report calls "focal centres", and what other people call centres of excellence. The report suggests that six or seven are needed which could include "the two or three in existence". But which laboratories are these? The report coyly refrains from naming any laboratory or centre but inevitably "existing centres" must mean the MRC laboratory at Cambridge and perhaps the National Institute of Medical Research at Mill Hill. The working group envisages these "focal centres" as part of universities, complementary to the science departments of the parent universities and providing research facilities for staff and post-doctoral fellows, and post-graduate training. On the American pattern, tenured associate professorships should be made available to outstanding younger men and the "focal centres" should be prepared to spend about $£ 2,500$ annually to provide facilities for each research worker.

It calls on the UGC, the research councils and the universities to put their heads together, declare their interest and make specific proposals in effect to bid for the centres. The report is now in the hands of the Department of Education and Science awaiting implementation.

\section{Computers Not On Tap}

Changes in the constitution of the Computer Board were predicted by its chairman, Professor B. H. Flowers, when he opened recently a hybrid computer facility at the Department of Engineering at Cambridge. Professor Flowers explained that there are two areas in which the board is unable to help the universities because its constitution specifically limits it to digital machines. For this reason, the board was unable to supply analogue machines or machines for teaching. The need for analogue or hybrid systems was not yet entirely clear, but Professor Flowers said that at a later stage it might seem sensible to extend the board's powers. On teaching, Professor Flowers said that the board had decided that there was need for a full study of computer teaching requirements as a separate issue and the UGC had agreed. A joint working party was being appointed to investigate the matter, and it was possible that the board's power would be extended to include teaching.

Professor Flowers also took the opportunity of explaining Science Research Council policy towards the support of science. Within each area of science, he said, there would be an increasing tendency to concentrate resources on schemes "most likely to yield substantial scientific advance or to be the basis of economic or social benefit". Already several subjects had been selected; these were control engineering, computer science, plasma physics, applied mathematics, astronomy, neutron beam techniques in biology, chemistry, metallurgy and physies, enzyme chemistry, industrial biology and polymer and material science. In all these areas, he said, the SRC was aiming for greater concentration of support in a more limited 